\title{
The utility of copy number variation (CNV) in studies of hypertension-related left ventricular hypertrophy (LVH): rationale, potential and challenges
}

\author{
Hoh BoonPeng ${ }^{1,2^{*}}$ and Khalid Yusoff ${ }^{2}$
}

\begin{abstract}
The ultimate goal of human genetics is to understand the role of genome variation in elucidating human traits and diseases. Besides single nucleotide polymorphism (SNP), copy number variation (CNV), defined as gains or losses of a DNA segment larger than $1 \mathrm{~kb}$, has recently emerged as an important tool in understanding heritable source of human genomic differences. It has been shown to contribute to genetic susceptibility of various common and complex diseases. Despite a handful of publications, its role in cardiovascular diseases remains largely unknown. Here, we deliberate on the currently available technologies for CNV detection. The possible utility and the potential roles of CNV in exploring the mechanisms of cardiac remodeling in hypertension will also be addressed. Finally, we discuss the challenges for investigations of CNV in cardiovascular diseases and its possible implications in diagnosis of hypertension-related left ventricular hypertrophy (LVH).
\end{abstract}

Keywords: Copy number variation, Genetic susceptibility, Hypertension, Left ventricular hypertrophy

\section{Introduction}

Genetic variation in human genome exists in different forms, ranging from large, cytogenetically visible chromosomal alterations to submicroscopic variations including structural changes involving insertion/deletion of large DNA segment, segmental duplication, copy number changes and inversion, to the molecular level of presence/ absence of transposable elements, variable number of tandem repeat (VNTR), and changes of a single base pair known as single nucleotide polymorphism (SNP).

SNP was thought to be the predominant form of variation in human genome and accounted for the majority of phenotypic variability [1]. A number of genome-wide association studies (GWAS) had reported the relation of these common variants in human disease susceptibility. For instance, the Wellcome Trust Case Control Consortium

\footnotetext{
* Correspondence: hbpeng@salam.uitm.edu.my

${ }^{1}$ Institute of Medical Molecular Biotechnology, Faculty of Medicine, Universiti Teknologi MARA, Sungai Buloh Campus, Jalan Hospital, 47000, Sungai, Buloh, Malaysia

${ }^{2}$ Faculty of Medicine, Universiti Teknologi MARA, Selayang Campus, Jalan

Prima 7, 68100Batu Caves, Selangor, Malaysia
}

(WTCCC) involving 17,000 samples, studied seven common diseases namely, hypertension, Crohn's disease, type I diabetes, type II diabetes, coronary heart disease, rheumatoid arthritis and bipolar disorder [2]. Many other GWASes have identified genetic associations of a wide range of common and complex diseases [eg. 3-7]. To date, the number of reported GWAS is still growing exponentially (http://www.genome.gov/gwastudies/).

Recently, an alternative form of genetic variation has gained much interest namely, Copy Number Variation (CNV). Since the first report [8,9], it has emerged as an important genetic marker in addition to SNP. It is conceivable that $\mathrm{CNV}$ will be taking its place alongside SNP in various genetic studies in the near future. Hence it is timely to review the potential role of $\mathrm{CNV}$ in understanding complex polygenic conditions in particular cardiovascular diseases, including hypertension and its complications. This review discusses the possible utility of $\mathrm{CNV}$ in delineating the mechanisms of cardiac remodeling in hypertension and its challenges in translation to clinical practice.

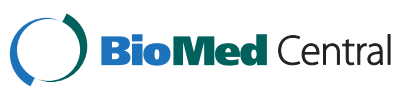

(c) 2013 BoonPeng and Yusoff; licensee BioMed Central Ltd. This is an Open Access article distributed under the terms of the Creative Commons Attribution License (http://creativecommons.org/licenses/by/2.0), which permits unrestricted use, distribution, and reproduction in any medium, provided the original work is properly cited. 


\section{Copy Number Variation (CNV)}

$\mathrm{CNV}$ is recognized as a form of structural variation, involving changes of copy number of a large segment of DNA ( $>1 \mathrm{~Kb})$ composed of duplications, deletions, and complex multi-site variants introduced by non-allelic homologous recombination $[10,11]$. It is by and large the most prevalent type of structural variation identified to date [12]. Figure 1 illustrates the types of genomic alterations resulting in the formation of structural variation and copy number variations in the genome.

Despite technological limitations in CNV discovery, this genetic marker is estimated to cover $\sim 12-15 \%$ of the human genome [13,14]. Interestingly, there is a significant relationship between the CNV regions and gene content - a substantial proportion of CNVs are found at the gene-enriched regions in particular those "environmental sensitive" genes, which influence the responses to environmental stimuli $[15,16]$. Indeed a significant association either with gene expression variability [17], or the important regulatory sequences that are situated far apart from the actual target gene [12].

Initially, CNV was thought to be pathogenic to rare genomic disorders $[12,18,19]$. However, this variability appears virtually in all "phenotypically normal" individuals reported to date $[8,9,20-22]$. It has been attributed to a number of susceptibility of common and complex diseases [23-28], neuropsychiatric diseases [29-33], and notably, cardiovascular diseases $[34,35]$.

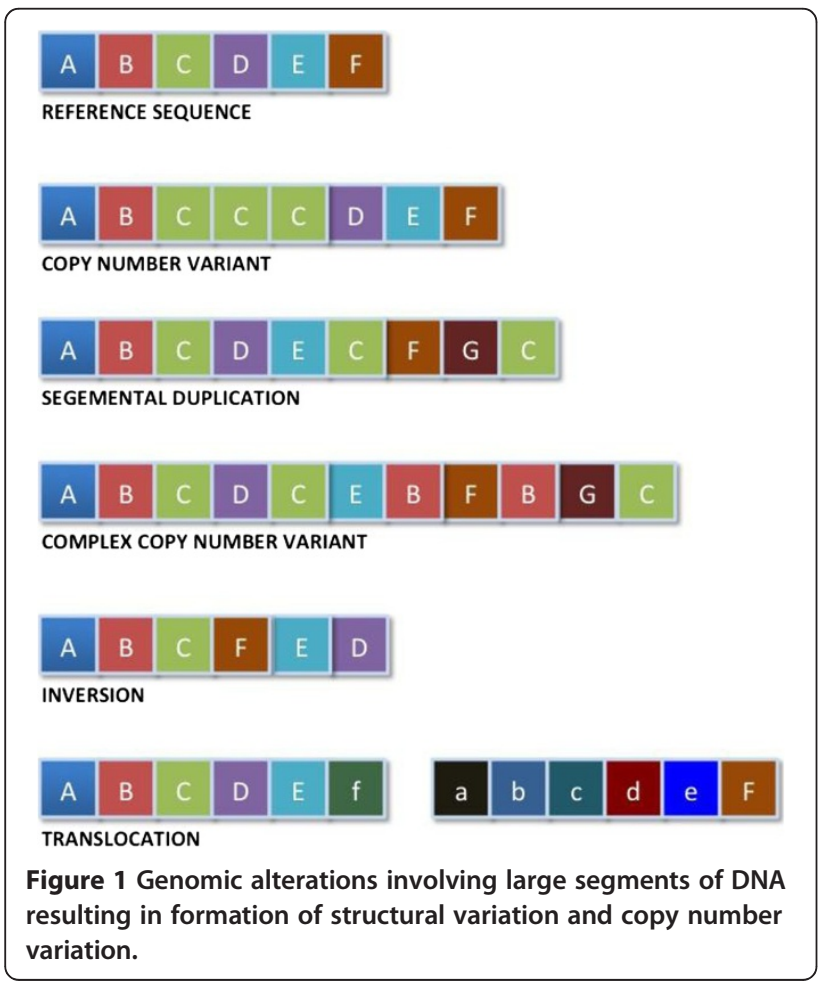

Technology for CNV detection and analysis

$\mathrm{CNV}$ can be detected and analyzed by different technologies, both at the genome-wide scale and the locus specific level. Details of these technologies have been well described [36,37].

At the genome-wide level, the following methods are predominantly in use currently:

i) array-Comparative Genomic Hybridization (aCGH). This assay uses an array of probes where differentially labeled test and reference DNA are jointly hybridized to the array [36,37]. Detection of $\mathrm{CNV}$ is based on the intensity ratio of the labeled probes. Two major technologies are available for aCGH. Agilent Technologies commercializes highdensity arrays, up to 1 million probes; while NimbleGen Technology produces arrays with 2.1 million probes.

ii) SNP array. Although this assay was originally developed for investigations of single nucleotide variation, it is increasingly being used to mine $\mathrm{CNVs}$, based on the probe intensity information obtained. In SNP array, no reference DNA is being labeled. Instead, CNV is identified via comparing the probe intensities of the test DNA with different individuals. Two major platforms are available in the industry. Affymetrix produces high-density "hybrid" arrays, accommodating 1.8 million of SNP and CNV probes. Whilst the Illumina produces up to 5 million SNP probes in a single array, the highest density in the microarray technology thus far. Whilst SNP array provides both information of SNP and $\mathrm{CNV}$ with a higher density, aCGH has a better signal accuracy. Another advantage of SNP array/ "hybrid" array over aCGH is its ability to identify the runs of homozygosity ( $\mathrm{ROH})$, providing a more informative analysis. $\mathrm{ROH}$ is defined as a large DNA segment (typically $>1 \mathrm{Mb}$ ) with the presence of uninterrupted homozygosity resulting from mutational events such as uniparental disomy (UPD), hemizygous deletion and loss of heterozygosity (LOH) [38]. Often it is challenging to distinguish between the $\mathrm{ROH}$ with a copy number deletion and with the presence of both homozygous alleles. SNP array has the ability to differentiate the two types of $\mathrm{ROH}$ via inspection of the genotype calls and probe signal intensity ratio simultaneously. Several studies on $\mathrm{ROH}$ and complex diseases have been reported recently $[39,40]$.

iii) Fluorescent in situ Hybridization (FISH). This approach was initially used to detect various syndromic diseases involving larger scale chromosomal alternations. It hybridizes fluorescently labeled probes to the chromosomal 
regions showing high sequence complementary, subsequently visualized under fluorescent microscopy. However, one major limitation of FISH in CNV analysis is its low resolution, making it incapable of accurately detecting any CNV smaller than $5 \mathrm{Mb}$ [36], thus rendering it inappropriate for study of common and complex disease like LVH.

At the locus specific level, technologies being utilized in $\mathrm{CNV}$ quantification of a particular candidate gene including, but not restricted to, Multiplex Ligation-dependent Probe Amplification (MLPA), quantitative PCR (qPCR), and Paralogue Ratio Test (PRT). MLPA utilizes the principle of multiplex PCR and ligation, simultaneously detecting $\mathrm{CNV}$ in multiple regions in a single reaction, based on its PCR ligated products. The copy number of the sample is the measurement of the intensity of the product relative to control DNA [41]. qPCR is the commonest and simplest assay for $\mathrm{CNV}$ analysis. It measures the fluorescence signals of the targeted sequence relative to a reference gene (e.g. FOXP2 and TERT) [41]. PRT uses a single primer pair to amplify precisely two products, one from the targeted $\mathrm{CNV}$ region and the other from a single copy reference locus [42]. Our experience suggests that PRT was more accurate in determining copy number calls compared to other PCR based assays.

The introduction of high throughput next generation sequencing has significantly increased the resolution and sensitivity of CNV detection. However, the cost of experiment is considerably higher and may not be affordable by most laboratories.

\section{Left Ventricular Hypertrophy (LVH)}

$\mathrm{LVH}$ is an independent risk factor for the development of clinical events such as heart failure, cardiac arrhythmias, stroke and cardiovascular mortality $[43,44]$. A recent report suggested the prevalence of $\mathrm{LVH}$ at $36 \%$ globally, based on echocardiographic studies [45]. In Malaysia, the prevalence of LVH was reported to be $24 \%$ based on echocardiography [46]. Initially it is a physiological response to hemodynamic and/or biomechanical stress, as in hypertension $[47,48]$. Later the hypertrophy is mal-adaptive and counterproductive, and impacts adversely on the prognosis. LVH remains a highly frequent indicator for cardiac damage among hypertensive patients [45]. The development of LVH in a patient with hypertension worsens the prognosis of the patient. This condition has a complex multifactorial and polygenic basis for its pathogenesis.

Control of hypertension and reversal of hypertensionrelated LVH is possible, resulting in improved prognosis. Identification of patients at risk for developing hypertension-related LVH may lead to early interventions to prevent its development, hence avoiding its sequelae and complications. This may further improve the prognosis and help increase adherence to treatment among these patients. Thus early diagnosis and improved understanding on the pathogenesis of LVH may lead to more effective therapeutic strategies [49].

\section{Genetics of LVH}

The molecular and biochemical pathways of $\mathrm{LVH}$ pathogenesis have been well described [43,44,47,50-52]. Briefly, mechanical input on the myocytes is transduced into biochemical event by initiation of signaling at the cell membrane. Neurohormonal and endocrine hormones (e.gAng II, EDN I, IGF I) bind to Angiotensin II type 1 and type 2, $\beta$-adrenegic and endothelin receptors which coupled to heteromeric Gq-proteins, induce phospholipase C (PLC) and protein kinase C (PKC) activation and subsequently production of inositol 1,4,5- triphosphate $[43,44,50]$ (Figure 2). Downstream, the release of $\mathrm{Ca}^{2+}$ triggers the calcineurin-calmodulin pathways, which activates various transcription factors including nucleus factor activated $\mathrm{T}$ cell (NFAT) and myocyte enhancer factor 2 (MEF2), JNKs, and GATAs $[44,47,50,52]$. The calcineurin pathway is also closely connected to several ion channel pathways, including

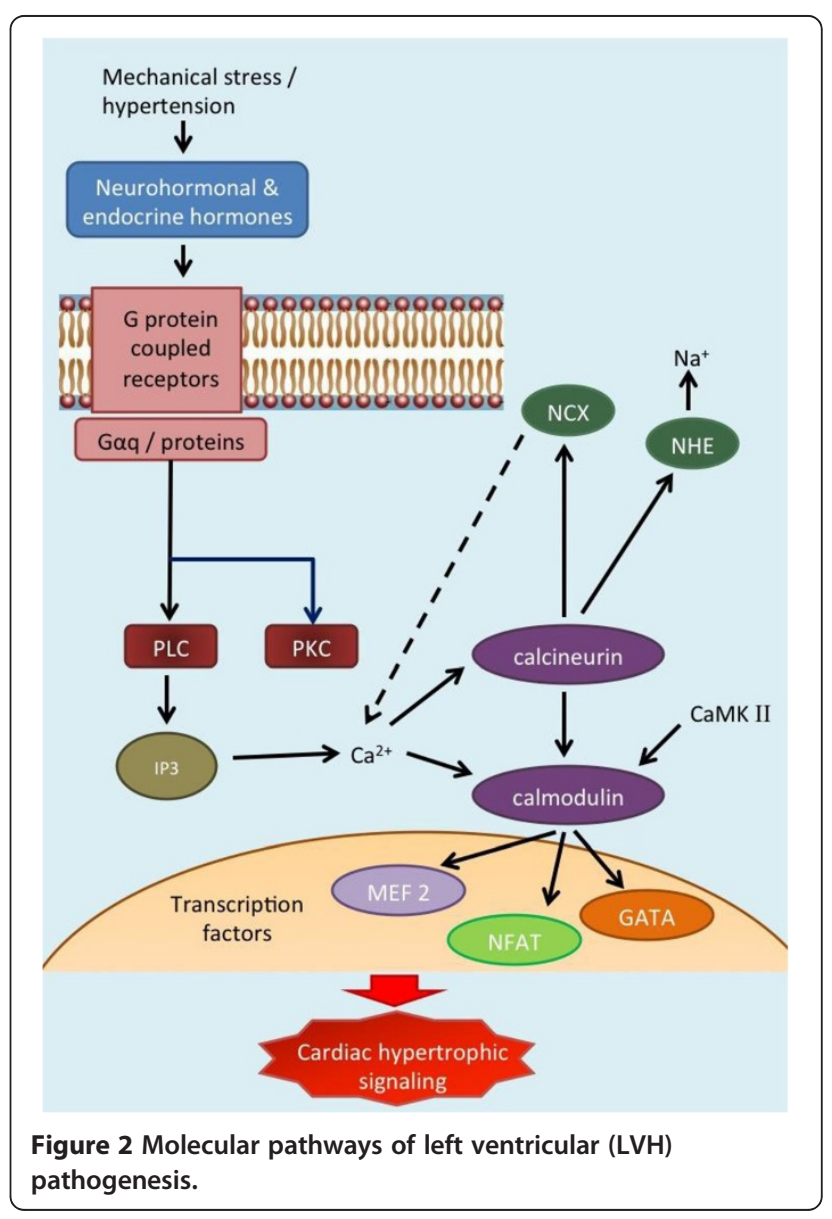


$\mathrm{Na}^{+} / \mathrm{Ca}^{2+}$-exchanger (NCX), and $\mathrm{Na} / \mathrm{H}$-exchanger (NHE) pathways. Activation of NHE pathway results in increased $\mathrm{Na}^{+}$, thus increasing the $\mathrm{Ca}^{2+}$ influx via $\mathrm{NCX}$ pathway, and initiating cardiac hypertrophy signaling. At the same time, NFAT transcription factor, which was triggered by calcineurin, interacts with the ANP/BNP pathways [43]. Other suggested pathways include, but not limited to, the PPAR, metalloproteinase (MMP) and mitogen-activated protein kinase (MAPK). The combination of these mechanisms conspires to initiate cardiac hypertrophy. These complex networks interacting with each other, together with pleiotropic and/or epistasis effects of the molecular pathways provide a substantial challenge to the efforts of mapping the causative genes.

$\mathrm{LVH}$ can be reversed by specific anti-hypertensive agents. Losartan, an angiotensin receptor blocker, has shown clinical benefit of this reversal beyond controlling the blood pressure [53]. Although a number of candidate gene association studies suggested the involvement of Renal Angiotensin System (RAS) in LVH pathogenesis, this association remains inconclusive, as results were not consistently replicated $[54,55]$. Notably, a genome-wide association study (GWAS) from the HyperGEN Study showed no significant association of RAS genes with LVH, instead calcineurin related genes seemed responsible for the development of LVH $[55,56]$. However when the same study cohort (HyperGEN) was tested on candidate genes ACE and AGT variants, significant association with LV mass was detected [57]. On top of that, a meta-GWAS published recently found no significant association signals of any of the RAS related gene with LV mass and function [58]; whilst Arnett et al. [59] reported that the NCAM1 was associated with LV wall thickness. Further, GallegoDelgado et al. [60] showed that RAS mediated genes were not up- nor down-regulated in a transcriptomic study. These findings further strengthen the evidence that the influence of RAS to LVH is most likely indirect. The mechanism of action of Losartan could possibly be explained thus: it selectively blocks Angiotensin II receptor I (AGTRI) but allowing continued signaling via Angiotensin II Receptor II (AGTRII) which reduces cellular proliferation, fibrosis and Matrix Metalloproteinase (MMP) activities by normalizing the calcineurin activity and the DNA binding of the NFAT signaling, yet increases apoptosis in cardiac cells $[61,62]$. Collectively, whether a strategy specific to reduce LVH provides additional clinical advantage or simply to reverse the complication by controlling blood pressure is debatable.

Several observations can be made based on the genetic studies of LVH:

i) Selection of candidate genes solely based on an understanding of the biochemical roles of encoded proteins is not comprehensive thus may lead to inappropriate selection of candidate genes or SNPs. Therefore, an unbiased approach (often with multiple hypotheses) such as genome-wide screening [63] is always recommended to study complex traits such as hypertension-related LVH. Further, interactions between genes and environment as well as haplotype analyses have been insufficient thus potential biological influence of a particular candidate gene may have been masked [64].

ii) Precise phenotyping. The first generation of GWAS completed by the Wellcome Trust Case-control Consortium (WTCCC) failed to achieve a genomewide significant level in hypertension [2] and up to $25 \%$ of the population based "controls" were misclassified [65]. This diluted the statistical effects thus biased towards null $[65,66]$. Therefore, obtaining a "clean" and standardized case and control group to one particular trait (example in this case, LV wall thickness, or LV mass) from a particular homogenous cohort is essential. In order to increase the power of detection, one should consider deriving samples from an extreme phenotype distribution [65], for instance the $10^{\text {th }}$ percentile versus the $90^{\text {th }}$ percentile of the LV wall thickness measurement $[67,68]$.

iii)Common traits (eg. blood pressure and LV wall or LV mass) may be controlled by many genes or loci (in a single or several pathophysiological pathways), each accounts a small portion of additive genetic effects on the phenotype. These common variants do not contribute to immediate effect to the deleterious phenotypes, rather to late onset common and complex diseases [69].

iv) "Missing heritability". The fact that the "unexplained reason(s)" of the relatively small fraction of individual disease risk (modest odd ratio of $~ 1.1-1.5$ ) suggest that there are missing puzzles when explaining the trait heritability [70,71]. Instead, the less common variants $(0.5-5 \%)$ or rare variants $(<0.5 \%)$ with stronger effect may play an equal role as of common variants, if not greater. Nonetheless, these variants are often too rare to be detected by common molecular tools to prove statistical evidence of association [69].

v) The influence of other forms of genome variations such as CNV. The potential of this variability is yet to be fully explored, therefore its impact on common diseases such as hypertension-related LVH is largely unknown. There has been arguments though, that common $\mathrm{CNV}$ is typable by tagSNP, therefore they contribute limited risk factor to disease susceptibility $[12,72]$. However, the complex, segmental duplicated and the rare de novo CNVs are not counted - at least not with the current genotyping platform (except for 
next generation sequencing) because they normally do not follow the Mendelian inheritance. In addition, CNV allelic size is often not "taggable" by these SNPs [12]. Typical examples are shown in a number of diseases $[23,24,27,30-32,73]$.

\section{CNV and the susceptibility of hypertension-related LVH}

Association between $\mathrm{CNV}$ and cardiovascular diseases has not been widely investigated hence less understood, except that those reviewed by Pollex and Hegele [74], which mainly described the monogenic disorders of cardiovascular diseases, and recently on familial dilated cardiomyopathy [34]. While studies on gene copy number of LPA gene in familial hypercholestrolemia (FH), atherosclerosis and coronary artery disease [19] were performed, the influence of $\mathrm{CNV}$ in non-familial cardiovascular diseases in particular hypertension-related LVH has not been widely reported. It is possible that $\mathrm{CNV}$ may be involved in pathogenesis of LVH via its potential biological effects on the candidate genes (ie regulating the gene dosage) in the respective pathways. Essentially, complex diseases like hypertension and other cardiovascular diseases, together with additive environmental factors, might be more prone to a "softer" form of variation such as CNVs, which alters the gene dosage (or regulations) without disrupting the functions. We have listed here some of the selected candidate genes and their molecular/biochemical pathways (mainly RAS, calcineurin-calmodulin, MAPK and other above mentioned related signaling pathways) which are believed to be involved in the pathogenesis of LVH. They often overlap with known or common CNV regions. The search was done through the Database of Genomic Variants (DGV; http://projects.tcag.ca/variation/) (date: $17^{\text {th }}$ May 2012) (Table 1).

Analysis of the CNV with hypertensive LVH though, should not limit to only those particular "gene-enriched" CNVs. Studies have shown that CNVs may have impact on disease susceptibility through their effects on nontranscribed domains that regulate gene expression at a distance $[10,16]$. On the other hand, the possible influence of rare or de novo CNV should not be ignored in particular some of the extreme cases. Typical successful example is shown in thoracic aortic aneurysms and dissections [34].

\section{Implications of CNV in clinical practice of LVH}

CNV has opened up potentials for both clinical cases and laboratory medicine. Its path may lead to the advancement for laboratory tests, which are used to be time consuming, labor intensive, expensive and at times difficult to interpret the result. Together with echocardiography and ECG examinations [75,76], CNV and/or SNP based genotyping could enrich the information for diagnosis, providing a more accurate and efficient detection tool, of which early intervention may be beneficial to hypertensive patients at risk of developing LVH. A successful example is the study reported by Wang et al. [77]. Coupled with the CNV of LPA gene and the SNP identified, this study managed to increase the detection rate of Familial Hypercholestrolemia (FH) up to $86.2 \%$. To the best of our knowledge, this study has yet to be replicated; but if successful, this result could be useful to design for $\mathrm{FH}$ diagnosis, and consequently be developed as a biomarker if functionally validated. The genetic profiles obtained may be useful to estimate disease risk, eg LVH, for the individual hypertensive patient.

In essence, large segment $\mathrm{CNV}$ alternations often involve numerous neighboring genes, thus shedding the light on the understanding of syndromology ie wide spectrum of variations and inconsistencies of phenotypic features [12]. Hypertension-related LVH, expressing a wide range of phenotypes, could be explained via gene mapping with CNV. Though, the applications of CNV in medical decisionmaking should be considered with caution at this present stage, due to the fact that frequencies of occurrence may vary in a particular population from another.

Despite hunting for causative variants, the primary value of genome-wide studies - either SNPs or CNVs mapping is to provide an etiological connection between biochemical pathways and disease, thus providing novel insights into the disease mechanisms. Consequently, knowledge of the disease pathways can be translated into strategies for prevention, diagnosis and therapy including drug development, new treatment and diagnostic approaches. Essentially candidate $\mathrm{CNVs}$ identified in both genome-wide scale, and locus specific assays, should be functionally validated and replicated in an independent cohort. Eventually specific tests of the particular $\mathrm{CNV}(\mathrm{s})$ could be developed in clinical practice.

\section{Major challenges of CNV in cardiovascular diseases}

Investigations of CNV in complex diseases, while tempting, are still in its developing stage. Several challenges are noted currently and expected to resolve in the near future, especially with the availability of the massively parallel high throughput sequencing:

i) Lack of replication in CNV callings and reference samples for comparison of results. Multiple commercial arrays available for $\mathrm{CNV}$ detection, each with different resolutions and analytic algorithms, bias towards the advantage of its own technology. This leads to a poor replication when reporting $\mathrm{CNV}$, and lack of a standardized reference sample set further complicates the analysis efforts [78].

ii) Limitation of the current array based technology (copy number calls). Due to limitation of the chemistry, the array-based platforms only allow 
Table 1 Candidate genes and their functions in hypertensive LHV pathogenesis

Gene Gene map locus

$\begin{array}{ll}\text { ATP6AP2 Xp11.4 } & \end{array}$

\section{Estrogen receptor signaling:}

EGFR

$7 p 11.2$

EGF

$4 q 25$

ADAM12

$10 \mathrm{q} 26.2$

ERBB2

$17 q 21.1$

ITGB2 (Beta-integrin)

$21 \mathrm{q} 22.3$

ITGB1BP2 (Melusin)

Xq13.1

\section{CALCINEURIN-CALMODULIN Ca ${ }^{2+}$ Signaling:}

PPP3CA (calcineurin A-alpha) $\quad 4 q 24$

CALM1 (calmodulin 1)

$14 q 32.11$

CALM3 (calmodulin 3)

$19 q 13.2$

CAMK2B (calmodulin kinase)

$7 p 14.3$

Ion channel pathway:

$\begin{array}{ll}\text { SLC8A1 (NCX1) } & 2 \mathrm{p} 22.1 \\ \text { SLC9A2 (NHE) } & 2 \mathrm{q} 12.1 \\ \text { KCNB2 } & 8 \mathrm{q} 13.3\end{array}$

\section{NFAT SIGNALING \& OTHERS TRANSCRIPTION FACTORS}

NFATC3

$16 \mathrm{q} 22.1$

ILF3

$19 p 13.2$

ITPR3@IPR3

$6 p 21.31$

\section{Gene function}

Muscular smooth muscle contraction. Renin and prorenin cellular receptor May mediate renin-dependent cellular responses by activating ERK1 and ERK2. By increasing the catalytic efficiency of renin in AGT/ angiotensinogen conversion to angiotensin I, it may also play a role in the renin-angiotensin system (RAS).

Receptor binding to epidermal growth factor. Required by Angll to mediate ERK activation thus plays a critical role in the LVH induced by Ang II.

Shedding of heparin-binding EGF by ADAM12, induce hypertrophic signaling via EGFR activation downstream through small $G$ proteins and the MAPK pathway.

Involved in skeletal muscle regeneration, specifically at the onset of cell fusion and macrophage-derived giant cells (MGC) and osteoclast formation from mononuclear precursors. Plays a centre role in cardiac hypertrophy by interacting with HB-EGF.

A member of the epidermal growth factor (EGF) receptor family of receptor tyrosine kinases. Essential in cardiac development. Involved in the EGFR signaling that drives many cellular responses, including changes in gene expression, cytoskeletal rearrangement, anti-apoptosis and increased cell proliferation.

Involved in cell adhesion as well as cell-surface mediated signalling. Links the extracellular matrix to the intracelluar cytoskeleton. Stretch sensor. Deletion of this gene/protein leads to cardiac pathology. Gene expression profile is upregulated in ERbeta knockout mice with cardiac hypertrophy.

Integrin interacting protein. Sensor of mechanical stress in cardiac myocytes. An essential component for the phosphorylation (inactivation) of GSK3-beta. Deletion of this gene leads to cardiac pathology.

Calcium dependent, calmodulin stimulated protein phosphatase.Ca2 +/calmodulin binding.

Mediates the control of large number of enzymes and other proteins by $\mathrm{Ca}^{2+}$. Involved in a genetic pathway that regulates the centrosome cycle and progression via cytokinesis.

Together with CALM1 and CALM2, these calmodulin genes give rise to five transcripts that are present in most tissues. This gene may be specifically and differently regulated during cardiac cell proliferation and/ or hypertrophy.

Calmodulin $/ \mathrm{Ca}^{2+}$ signaling. At basal $\mathrm{Ca}^{2+}$ levels, CaMKs are maintained in a dormant state through autoinhibition. Increase in $\mathrm{Ca}^{2+}$ levels allows calmodulin to relieve this autoinhibition and activate the kinase activity.

Sodium-Calcium exchange pathway

Sodium-Hydrogen exchange pathway

Regulate the smooth muscle contraction by controlling the influx of $\mathrm{Ca}^{2+}$ through voltage-gated $\mathrm{Ca}^{2+}$ channels

Required in muscle cell, and heart development, as well as smooth muscle differentiation. Rapid nuclear exit of NFATC is thought to be onemechanism by which cells distinguish between sustained and transient calcium signals.

Involved in the NFAT transcription signaling. A subunit of the nuclear factor of activated T-cells (NFAT).

Inositol 1,4,5-triphosphate receptor type 3. Involved in mediating the release of intracellular calcium. 


\section{Table 1 Candidate genes and their functions in hypertensive LHV pathogenesis (Continued)}

\begin{tabular}{|c|c|c|}
\hline GATA4 & 8p23.1 & $\begin{array}{l}\text { Transcription factors that regulate genes critical for myocardial } \\
\text { differentiation and function, regulates hypertrophic gene expression. }\end{array}$ \\
\hline MCIP-1 (RCAN1) & $21 q 22.12$ & $\begin{array}{l}\text { Modulatory calcineurin interacting protein. Serves as calcineurin- } \\
\text { regulatory protein that inhibit calcineurin when over expressed. }\end{array}$ \\
\hline MEF2A & $15 q 26.3$ & $\begin{array}{l}\text { Transcription factor of cardiac hypertrophy cascade. Involved in the } \\
\text { activation of numerous growth factor- and stress-induced genes. Mediates } \\
\text { cellular functions in skeletal and cardiac muscle development. }\end{array}$ \\
\hline MAPK3 & $16 p 11.2$ & $\begin{array}{l}\text { Act as a signaling cascade that regulates various cellular processes } \\
\text { including proliferation, differentiation and cell cycle progression in } \\
\text { response to a variety of extracellular signals. }\end{array}$ \\
\hline JAK2 & $9 p 24.1$ & $\begin{array}{l}\text { Involved in a specific subset of cytokine receptor signaling pathways. } \\
\text { Uponreceptor activation JAKs phosphorylate the transcription factors } \\
\text { known as STATs and initiate the JAK-STATsignaling pathway. }\end{array}$ \\
\hline CTNNB1 (Beta-catenin) & 3p22.1 & $\begin{array}{l}\text { Cadherin-associated protein. Part of a complex of proteins that constitute } \\
\text { adherens junctions. Involved in the regulation of cell adhesion. } \\
\text { Predominantly localized to the cell membrane, and is part of E-cadherin } \\
\text { /catenin adhesion complexes which are believed to couple cadherins to } \\
\text { the actin cytoskeleton. Structural changes of the extracellular matrix in } \\
\text { LVH are significantly modulated by B-catenin associated signaling } \\
\text { pathways. }\end{array}$ \\
\hline
\end{tabular}

$\mathrm{CNV}$ detection of gain or loss of two copies $(\mathrm{CN}=0$ - 4). Thus, analysis of multiple or complex CNV has always been a challenge.

In view of the above mentioned difficulties, $\mathrm{CNV}$ is usually called by three algorithms, and the consensus of at least two is defined as "stringent" CNV call [36]. In addition, validation approaches with other techniques are always recommended to confirm the CNV detected, for instance, qPCR, MLPA, paralogue ratio test (PRT), CGH and FISH (for large CNVs) $[13,79,80]$.

iii) Identification of precise breakpoint is a common issue of CNV study. Often, the non-identical, but overlapping copy number alleles is being assigned into one category, or being misinterpreted as the same allele. This will definitely affect tests of association between variation and disease, as different breakpoints may result in different biological consequences. DNA sequencing of the region of interest may resolve this problem. However, it is laborious in Sanger sequencing for such purpose [81]; the cost for next-generation sequencing is expected to be lower in the future though.

iv) Careful interpretation of the complex CNV data in both research and medical decision-making is essential especially when dealing with complex diseases. How CNV results are applied to research or medical decision-making needs to be considered according to the circumstances where it is observed especially with the awareness of interactions between single nucleotide alterations and $\mathrm{CNVs}$ [12]. Unexplained familial disorders should be revised with the consideration of the presence of above mentioned potential technical limitations. Potential challenge between genomic observation and clinical implication could be raised when complex conditions like cardiovascular diseases require a shift of mindset to approaches like rare CNVs.

v) The need for an established database, both for "healthy" populations (such as Database for Genomic Variants, DGV), or disease cohort (such as DECIPHER) will be essential, cataloging the information of genic content of the variant segment $[12,82]$. This would help to narrow down the disease diagnosis by excluding those non-pathogenic, and focus on the disease-based CNVs.

vi) Cost consideration versus selection of technology. Effective running cost and ease of assay typing have always been the major hindrance for clinicians in $\mathrm{CNV}$ analysis. Although the cost for an array-based global CNV screening has dropped, it is unaffordable by most patients especially those from the lower income community. Although locus specific CNV genotyping assays are more cost effective, lower resolution and limited information obtained (as discussed in the earlier section) from such assays is a drawback. Therefore, comprehensive $\mathrm{CNV}$ mapping and identification of pathogenic $\mathrm{CNV}$ in LVH is needed to ensure that the findings be translated into clinical practice in the most cost effective manner.

\section{Conclusion}

Molecular cardiological research with $\mathrm{CNV}$ provides ample possibilities for the development of more cardiac-specific 
pharmaceutical interventions, which could be tailor made to the pathology and genetic make-up of the individual patient. The application of CNV in complex diseases will continue to grow while array based technology will remain as the mainstay in the next future. Ongoing development of technological and sophisticated statistical tools in CNV analysis should warrant the extensive investigation of the genetics of LVH. However, the growth of this research area is still in its infancy stage and far from translating into medical implication, thus efficacy of such an approach should be carefully interpreted.

\section{Competing interests}

The authors declare that they have no competing interests.

\section{Authors' contributions}

HBP and KY wrote and edited the paper. All authors read and approved the final manuscript.

\section{Acknowledgement}

This work is supported by the Fundamental Research Grant Scheme (FRGS) of Ministry of Higher Education Malaysia in 2007 (211501080005 [ST FRGS 1342]) and 2010 (600-RMI/ST/FRGS 5/3 Fst [61/2010]).

Received: 21 September 2012 Accepted: 3 January 2013

Published: 1 March 2013

\section{References}

1. The International HapMap Consortium: A Haplotype Map of the Human Genome. Nature 2005, 437:1299-1320.

2. The Wellcome Trust Case Control Consortium: Genome-wide association study of 14000 cases of seven common diseases and 3000 shared controls. Nature 2007, 447:661-678.

3. Adeyemo A, Gerry N, Chen G, Herbert A, Doumatey A, Huang H, Zhou J, Lashley K, Chen Y, Christman M, Rotimi C: A genome-wide association study of hypertension and blood pressure in African Americans. PLoS Genet 2009, 5(7):e10000564.

4. Trégouët D, König IR, Erdmann J, Munteanu A, Braund PS, Hall AS, Grohennig A, Linsel-Nitschke P, Perret C, De Suremain M, Meitinger T, Wright BJ, Preuss M, Balmforth AJ, Ball SG, Meisinger C, Germain C, Evans A, Arveiler D, Luc G, Ruidavets J, Morrison C, van der Harst P, Schreiber S, Neureuther K, Schäfer A, Bugert P, Mokhtari NEEl, Schrezenmeir J, et al: Genome-wide haplotype association study identifies the SLC22A3-LPAL2-LPA gene cluster as risk locus for coronary artery disease. Nat Genet 2009, 41:283-285.

5. Bouatia-Naji N, Rocheleau G, Van Lommel L, Lemaire K, Schuit F, CavalcantiProença C, Marchand M, Hartikainen AL, Sovio U, De Graeve F, Rung J, Vaxillaire M, Tichet J, Marre M, Balkau B, Weill J, Elliott P, Jarvelin MR, Meyre D, Polychronakos C, Dina C, Sladek R, Froguel P: A polymorphism within the G6PC2 gene is associated with fasting plasma glucose levels. Science 2008, 320:1085-1088.

6. Chioza BA, Aicardi J, Aschauer H, Brouwer O, Callenbach P, Covanis A, Dooley JM, Dulac O, Durner M, Eeg-Olofsson O, Feucht M, Friis ML, Guerrini R, Kjeldsen MJ, Nabbout R, Nashef L, Sander T, Sirén A, Wirrell E, McKeigue P, Robinson R, Gardiner RM, Everetta KV: Genome wide high density SNP-based linkage analysis of childhood absence epilepsy identifies a susceptibility locus on chromosome 3p23-p14. Epilepsy Res 2009, 87:247-255.

7. Thorleifsson G, Magnusson KP, Sulem P, Walters GB, Gudbjartsson DF, Stefansson $\mathrm{H}$, Jonsson T, Jonasdottir A, Jonasdottir A, Stefansdottir $\mathrm{G}$, Masson M, Hardarson GA, Petursson H, Arnarsson A, Motallebipour M, Wallerman O, Wadelius C, Gulcher JR, Thorsteinsdottir U, Kong A, Jonasson $\mathrm{F}$, Stefansson K: Common sequence variants in the LOXL1 gene confer susceptibility to exfoliation glaucoma. Science 2007, 317:1397-1400.

8. Sebat J, Lakshmi B, Troge J, Alexander J, Young J, Lundin P, Månér S, Massa H, Walker M, Chi M, Navin N, Lucito R, Healy J, Hicks J, Ye K, Reiner A, Gilliam TC, Trask B, Patterson N, Zetterberg A, Wigler M: Large-scale copy number polymorphism in the human genome. Science 2004, 305:525-528.
9. lafrate JA, Feuk L, Rivera MN, Listewnik ML, Donahoe PK, Qi Y, Scherer SW, Lee C: Detection of large-scale variation in the human genome. Nat Genet 2004, 36:949-951.

10. Feuk L, Carson AR, Scherer SW: Structural variation in the human genome. Nat Rev Genet 2006, 7:85-97.

11. Freeman JL, Perry GH, Feuk L, Redon R, McCarroll SA, Altshuler DM, Aburatani H, Jones KW, Tyler-Smith C, Hurles ME, Carter NP, Scherer SW, Lee C: Copy number variation: New insights in genome diversity. Genome Res 2006, 16:949-961.

12. Lee C, Scherer SW: The clinical context of copy number variation in the human genome. Exp Rev Mol Med 2010, 12:e8.

13. Redon R, Ishikawa S, Fitch KR, Feuk L, Perry GH, Andrews TD, Fiegler H, Shapero MH, Carson AR, Chen W, Cho EK, Dallaire S, Freeman JL, González JR, Gratacòs M, Huang J, Kalaitzopoulos D, Komura D, MacDonald JR, Marshall CR, Mei R, Montgomery L, Nishimura K, Okamura K, Shen F, Somerville MJ, Tchinda J, Valsesia A, Woodwark C, Yang F, et al: Global variation in copy number in the human genome. Nature 2006, 444:444-454.

14. Estivill $X$, Armengol L: Copy number variants and common disorders: filling the gaps and exploring complexity in genome-wide association studies. PLoS Genet 2007, 3(10):1787-1799.

15. Cooper GM, Nickerson DA, Eichler EE: Mutational and selective effects on copy-number variants in the human genome. Nat Genet 2007, 39:S22-S29.

16. Korbel JO, Kim PM, Chen X, Urban AU, Weissman S, Snyder M, Gerstein MB: The current excitement about copy-number variation: how it relates to gene duplication and protein families. Curr Opin Struc Biol 2008, 18:366-374

17. Stranger BE, Forrest MS, Dunning M, Ingle CE, Beazley C, Thorne N, Redon R, Bird CP, de Grassi A, Lee C, Tyler-Smith C, Carter N, Scherer SW, Tavaré S, Deloukas P, Hurles ME, Dermitzakis ET: Relative impact of nucleotide and copy number variation of gene expression phenotypes. Science 2007, 315:848-853.

18. Emanuel BS, Shaikh TH: Segmental duplications: an 'expanding' role in genomic instability and disease. Nat Rev Genet 2001, 2:791-800.

19. Fanciulli M, Petretto E, Aitman TJ: Gene copy number variation and common human disease. Clin Genet 2010, 77:201-213.

20. Armengol L, Villatoro S, González JR, Pantano L, García-Aragonés M, Rabionet R, Cáceres M, Estivill X: Identification of copy number variants defining genomic differences among major human groups. PLOS One 2009, 4:e7230

21. Yim S, Kim T, Hu H, Kim J, Kim B, Lee J, Han B, Shin S, Jung S, Yeun-Jun C: Copy number variations in East-Asian population and their evolutionary and functional implications. Hum Mol Genet 2010, 19:1001-1008.

22. Ku CS, Pawitan YP, Sim X, Ong RT, Seielstad M, Lee EJ, Teo YY, Chia KS, Salim A: Genomic copy number variation in three Southeast Asian Populations. Hum Mutat 2010, 31:851-857.

23. Gonzalez E, Kulkarni H, Bolivar H, Mangano A, Sanchez R, Catano G, Nibbs RJ, Freedman BI, Quinones MP, Bamshad MJ, Murthy KK, Rovin BH, Bradley W, Clark RA, Anderson SA, O'connell RJ, Agan BK, Ahuja SS, Bologna R, Sen L, Dolan MJ, Ahuja SK: The influence of CCL3L1 gene-containing segmental duplications on HIV-1/AIDS susceptibility. Science 2005 307:1434-1440.

24. Milanese M, Segat L, Arraes LC, Garzino-Demo A, Crovella S: Copy number variation of defensin genes and HIV infection in Brazilian children. $J$ Acquir Immne Def Synd 2009, 50:331-333.

25. Frank B, Hemminki K, Meindl A, Wappenschmidt B, Sutter G, Frank B, Hemminki K, Meindl A, Wappenschmidt B, Sutter C, Kiechle M, Bugert P, Schmutzler RK, Bartram CR, Burwinkel B: BRIP1 (BACH1) variants and familial breast cancer risk: a case-control study. BMC Cancer 2007, 7:83.

26. Ingelman-Sundberg M, Sim SC, Gomez A, Rodriguez-Antona C: Influence of cytochrome P450 polymorphism on drug therapies: pharmacogenetic, pharmacoepigenetic and clinical aspects. Pharm Ther 2007, 116:496-526.

27. Aitman TJ, Dong R, Vyse TJ, Norsworthy PJ, Johnson MD, Smith J, Mangion J, Roberton-Lowe C, Marshall AJ, Petretto E, Hodges MD, Bhangal G, Patel SG, Sheehan-Rooney K, Duda M, Cook PR, Evans DJ, Domin J, Flint J, Boyle JJ, Pusey CD, Cook HT: Copy number polymorphism in Fcgr3 predisposes to glomerulonephritis in rats and humans. Nature 2006, 439:851-855.

28. de Cid R, Riveira-Munoz E, Zeeuwen PLJM, Robarge J, Liao W, Dannhauser EN, Giardina E, Stuart PE, Nair R, Helms C, Escaramís G, Ballana E, MartínEzquerra G, den Heijer M, Kamsteeg M, Joosten I, Eichler EE, Lázaro C, Pujol RM, Armengol L, Abecasis G, Elder JT, Novelli G, Armour JAL, Kwok PY, Bowcock A, Schalkwijk J, Estivill X: Deletion of the late cornified envelope 
LCE3B and LCE3C genes as a susceptibility factor for psoriasis. Nat Genet 2009, 41:211-215.

29. Rovelet-Lecrux A, Hannequin D, Raux G, Le Meur N, Annie Laquerrière A, Vital A, Dumanchin C, Feuillette S, Brice A, Vercelletto M, Dubas F, Frebourg T, Campion D: APP locus duplication causes autosomal dominant early-onset Alzheimer disease with cerebral amyloid angiopathy. Nat Genet 2006, 38:24-26.

30. Lachman HM, Pedrosa E, Petruolo OA, Cockerham M, Papolos A, Novak T, Papolos DF, PavlaStopkova: Increase GSK3beta gene copy number variation in bipolar disorder. Am J Med Genet B Neuropsychiatr Genet 2007, 144:259-265.

31. Sebat J, Lakshmi B, Malhotra D, Troge J, Lese-Martin C, Walsh T, Yamrom B, Yoon S, Krasnitz A, Kendall J, Leotta A, Pai D, Zhang R, Lee YH, Hicks J, Spence SJ, Lee AT, Puura K, Lehtimäki T, Ledbetter D, Gregersen PK, Bregman J, Sutcliffe JS, Jobanputra V, Chung W, Warburton D, King MC, Skuse D, Geschwind DH, Gilliam TC, Ye K, Wigler M: Strong association of de novo copy number mutation with autism. Science 2007, 316:445-449.

32. Pinto D, Pagnamenta AT, Klei L, Anney R, Merico D, Regan R, Conroy J, Magalhaes TR, Correia C, Abrahams BS, Almeida J, Bacchelli E, Bader GD, Bailey AJ, Baird G, Battaglia A, Berney T, Bolshakova N, Bölte S, Bolton PF, Bourgeron T, Brennan S, Brian J, Bryson SE, Carson AR, Casallo G, Casey J, Chung $\mathrm{BH}$, Cochrane $\mathrm{L}$, Corsello $\mathrm{C}$, et al: Functional impact of global rare copy number variation in autism spectrum disorders. Nature 2010, 466:368-372.

33. Xu B, Roos JL, Levy S, van Rensburg EJ, Gogos JA, Karayiorgou M: Strong association of de novo copy number mutations with sporadic schizophrenia. Nat Genet 2008, 40:880-885.

34. Norton N, Li D, Rieder MJ, Siegfried JD, Rampersaud E, Züchner S, Mangos S, Gonzalez-Quintana J, Wang L, McGee S, Reiser J, Martin E, Nickerson DA, Hershberger RE: Genome-wide studies of copy number variation and exome sequencing identify rare variants in BAG3 as a cause of dilated cardiomyopathy. Am J Hum Genet 2011, 88:1-10.

35. Prakash SK, LeMaire SA, Guo DC, Russell L, Regalado ES, Golabbakhsh H, Johnson RJ, Safi HJ, Estrera AL, Coselli JS, Bray MS, Leal SM, Milewicz DM, Belmont JW: Rare copy number variants disrupt genes regulating vascular smooth muscle cell adhesion and contractility in sporadic thoracic aortic aneurysms and dissections. Am J Hum Genet 2010, 87:743-756.

36. Carter NP: Methods and strategies for analyzing copy number variation using DNA microarrays. Nat Genet 2007, 39:S16-S21.

37. Leea $J$, Jeon JT: Methods to detect and analyze copy number variations at the genome-wide and locus-specific levels. Cytogenet Genome Res 2008, 123:333-342

38. Ku CS, Naidoo N, Teo SM, Pawitan Y: Regions of homozygosity and their impact on complex diseases and traits. Hum Genet 2011, 129:1-15.

39. Yang H-C, Chang L-C, Liang Y-J, Lin C-H, Wang P-L: A genome-wide homozygosity association study identifies runs of homozygosity associated with rheumatoid arthritis in the human major histocompatibiliy complex. PLOS ONE 2012, 7(4):34840. doi:10.1371/journal.pone.0034840.

40. Keller MC, Simonson MA, Ripke S, Neale BM, Gejman PV, Howrigan DP, Lee SH, Lencz T, Levinson DF, Sullivan PF: The Schizophrenia Psychiatric Genome-Wide Association Study Consortium: Runs of homozygosity implicate autozygosity as a schizophrenia risk factor. PLoS Genet 2012, 8(4):1002656. doi:10.1371/journal.pgen.1002656.

41. Stuppia L, Antonucci I, Palka G, Gatta V: Use of the MLPA Assay in the Molecular Diagnosis of Gene Copy Number Alterations in Human Genetic Diseases. Int. J. Mol. Sci. 2012, 13:3245-3276.

42. Armour JA, Palla R, Zeeuwen PL, Heijer MD, Schalkwijk J, Hollox EJ: Accurate, high-throughput typing of copy number variation using paralogue ratios fromdispersed repeats. Nucleic Acids Res 2007, 35:e19.

43. Lorell BH, Carabello BA: Left ventricular hypertrophy: pathogenesis, detection and prognosis. Circulation 2000, 102:470-479.

44. Heineke J, Molkentin JD: Regulation of cardiac hypertrophy by intracellular signalling pathways. Nat Rev Mol Cell Biol 2006, 7:589-600.

45. Cuspidi C, Sala C, Negri F, Mancia G, Morganti A: Prevalence of leftventricular hypertrophy in hypertension: an updated review of echocardiographic studies. J Hum Hypertens 2012, 26:343-349.

46. Ching SM, Chong WP, Azman WAN, Chia YC: Prevalence of left ventricular hypertrophy and its associated Factors Among Hypertensive Patients in An Outpatient Clinic. J Hypertens 2010, 28:e361-e362.

47. Meijs MFL, de Windt $L$, de Jonge N, Cramer MJ, Bots ML, Mali WP, Doevendans PA: Left Ventricular Hypertrophy: A shift in paradigm. Curr Med Chem 2007, 14:157-171.
48. Drazner MH: The Progression of Hypertensive Heart Disease. Circulation 2011, 123:327-334

49. Katholi RE, Couri DM: Left Ventricular Hypertrophy: Major Risk Factor in Patients with Hypertension: Update and Practical Clinical Applications. Intl J Hypertens 2011, 2011:495349.

50. Dorn GW II: The fuzzy logic of physiological cardiac hypertrophy. Hypertension 2007, 49:962-970.

51. Elton TS, Martin MM: Angiotensin II type I receptor gene regulation: transcriptional and posttranscriptional mechanisms. Hypertension 2007, 49:953-961.

52. Frohlich ED, Gonzalez A, Diez J: Hypertensive left ventricular hypertrophy risk: beyond adaptive cardiomyocytic hypertrophy. J Hypertens 2011, 29:17-26.

53. Dahlof B, Devereux RB, Kjeldsen SE, Julius S, Beevers G, de Faire U, Fyhrquist $\mathrm{F}$, Ibsen $\mathrm{H}$, Kristiansson $\mathrm{K}$, Lederballe-Pedersen $\mathrm{O}$, Lindholm LH, Nieminen MS, Omvik P, Oparil S, Wedel Hand LIFE Study Group: Cardiovascular morbidity and mortality in the Losartan Intervention for Endpoint reduction in hypertension study (LIFE): a randomised trial against atenolo. Lancet 2002, 359:995-1003.

54. Shlyakhto EV, Shwartz El, Nefedova YB, Zukova AV, Vinnic TA, Conrady AO: Lack of association of the renin-angiotensin system genes polymorphisms and left ventricular hypertrophy in hypertension. Blood Press 2001, 10:135-141.

55. Matthias H, Heinz V, Stefanie J, Reibis R, Van D, Juliane B, Irina Z, Roland ES, Andras T, Karl W, Reinhold K: Role of angiotensin II type 2 receptor gene (+1675 G/A) polymorphism on left ventricular hypertrophy and geometry in treated hypertensive patients. J Hypertens 2010, 28:1221-1229.

56. Arnett DK, Li N, Tang W, Rao DC, Devereux RB, Claas SA, Kraemer R, Broeckel U: Genome-wide association study identifies single-nucleotide polymorphism in KCNB1 associated with left ventricular mass in humans: The HyperGEN Study. BMC Genet 2009, 10:43.

57. Lynch Al, Tang W, Shi G, Devereux RB, Eckfeldt JH, Arnett DK: Epistatic effects of ACE I/D and AGT gene variants on left ventricular mass in hypertensive patients: the HyperGEN study. J Hum Hypertens 2012, 26:133-140.

58. Vasan RS, Glazer NL, Felix JF, Lieb W, Wild PS, Felix SB, Watzinger N, Larson MG, Smith NL, Dehghan A, Großhennig A, Schillert A, Teumer A, Schmidt R, Kathiresan S, Lumley T, Aulchenko YS, König IR, Zeller T, Homuth G, Struchalin M, Aragam J, Joshua C, Rivadeneira F, Erdmann J, Schnabel RB, Dörr M, Zweiker R, Lind L, Rodeheffer RJ: Genetic variants associated with cardiac structure and function: a meta-analysis and replication of genome-wide association data. J Am Med Assoc 2009, 302:167-178.

59. Arnett DK, Meyers KJ, Devereux RB, Tiwari HK, Gu CC, Vaughan LK, Perry RT, Patki A, Claas SA, Sun YV, Broeckel U, Kardia SL: Genetic Variation in NCAM1 contributes to left ventricular wall thickness in hypertensive families. Circ Res 2011, 108:279-283.

60. Gallego-Delgado J, Connolly SB, Lázaro A, Sadlier D, Kieran NE, Sugrue DD, Doran P, Brady HR, Osende J, Egido J: Transcriptome of hypertensioninduced left ventricular hypertrophy and its regression by antihypertensive therapies transcriptome of left ventricular hypertrophy. Hypertens Res 2009, 32:347-357.

61. Habashi JP, Doyle JJ, Holm TM, Aziz H, Schoenhoff F, Bedja D, Chen Y, Modiri AN, Judge DP, Dietz HC: Angiotensin II type 2 receptor signalling attenuates aortic aneurysm in mice through ERK antagonism. Science 2011, 332:361-365.

62. Saygili E, Rana OR, Meyer C, Gemain C, Andrzejewski MG, Ludwig A, Weber C, Schotten U, Kruttgen A, Weis J, Schwinger RHG, Mischke K, Rassaf T, Kelm $M$, Schanerte $P$ : The angiotensin-calcineurin-NFAT pathway mediates stretch-induced up-regulation of matrix metalloproteinases $-2 /-9$ in atrial myocytes. Basic Res Cardiol 2008, 104:435-448.

63. Pearson TA, Manolio TA: How to interpret a genome-wide association study. J Am Med Assoc 2008, 299:1335-1344.

64. Meyers KJ, Chu J, Mosley TH, Kardia SLR: SNP-SNP interactions dominate the genetic architecture of candidate genes associated with left ventricular mass in African-Americans of the GENOA study. BMC Med Genet 2010, 11:160

65. Zhang K, Weder AB, Eskin E, O'Connor DT: Genome-wide case/control studies in hypertension: only the 'tip o the iceberg'. J Hypertens 2010, 28:1115-1123.

66. McCarthy MI, Abecasis GR, Cardon LR, Goldstein DB, Little J, loannidis JP, Hirschhorn JN: Genome-wide association studies for complex traits: consensus, uncertainty, and challenges. Nat Rev Genet 2008, 9:356-369. 
67. Harrap SB, Davidson HR, Connor JM, Soubrier F, Corvol P, Fraser R, Foy CJ, Watt GC: The angiotensin I converting enzyme gene and predisposition to high blood pressure. Hypertension 1993, 21:455-460.

68. Rana BK, Insel PA, Payne SH, Abel K, Beutler E, Ziegler MG, Schork NJ, O'Connor DT: Population-based samples reveals gender-gender interactions in blood pressure in White Americans. Hypertension 2007, 49:96-106.

69. Altshuler D, Daly MJ, Lander ES: Genetic mapping in human disease. Science 2008, 322:881-888

70. Manolio TA, Collins FS, Cox NJ, Goldstein DB, Hindorff LA, Hunter DJ, McCarthy Ml, Ramos EM, Cardon LR, Chakravarti A, Cho JH, Guttmacher AE, Kong A, Kruglyak L, Mardis E, Rotimi CN, Slatkin M, Valle D, Whittemore AS, Boehnke M, Clark AG, Eichler EE, Gibson G, Haines JL, Mackay TFC, McCarroll SA, Visscher PM: Finding the missing heritability of complex diseases. Nature 2009, 46:747-753.

71. MCCarthy MI: Exploring the unknown: assumptions about allelic architecture and strategies for susceptibility variant discovery. Genome Medic 2009, 1:66

72. The Wellcome Trust Case Control Consortium: Genome-wide association study of CNVs in 16,000 cases of eight common diseases and 3,000 shared controls. Nature 2010, 464:713-720.

73. Walsh T, McClellan JM, McCarthy SE, Addington AM, Pierce SB, Cooper GM, Nord AS, Kusenda M, Malhotra D, Bhandari A, Stray SM, Rippey CF, Roccanova P, Makarov V, Lakshmi B, Findling RL, Sikich L, Stromberg T, Merriman B, Gogtay N, Butler P, Eckstrand K, Noory L, Gochman P, Long R, Chen Z, Davis S, Baker C, Eichler EE, Meltzer PS, et al: Rare structural variants disrupt multiple genes in neurodevelopmental pathways in schizophrenia. Science 2008, 320:540-543.

74. Pollex RL, Hegele RA: Copy number variation in the human genome and its implications for cardiovascular disease. Circulation 2007, 115:3130-3138.

75. Binder J, Ommen SR, Gersh BJ, Van Driest SL, Tajik AJ, Nishimura RA, Ackerman MJ: Echocardiography-guided genetic testing in hypertrophic cardiomyopathy: septal morphological features predict the presence of myofilament mutations. Mayo Clin Proc 2006, 81:459-467.

76. Bos JM, Towbin JA, Ackerman MJ: Diagnostic, prognostic, and therapeutic implications of genetic testing for hypertrophic cardiomyopathy. J Am Coll Cardio 2009, 54:201-211.

77. Wang J, Ban MR, Hegele RA: Multiplex ligation-dependent probe amplification of LDLR enhances molecular diagnosis of familial hypercholestrolemia. J Lipid Res 2005, 46:366-372.

78. Pinto D, Darvishi $K$, Shi $X$, Rajan D, Rigler D, Fitzgerald T, Lionel AC, Thiruvahindrapuram B, MacDonald JR, Mills R, Prasad A, Noonan K, Gribble S, Prigmore E, Donahoe PK, Smith RS, Park JH, Hurles ME, Carter NP, Lee C, Scherer SW, Feuk L: Comprehensive assessment of array-based platforms and calling algorithms for detection of copy number variants. Nat Biotech 2011, 29:512-520

79. Fernando MMA, Boteva L, Morris DL, Zhou B, We YL, Lokki M, Yu CY, Rioux JD, Hollox ED, Vyse TJ: Assessment of complement C4 gene copy number using the paralog ratio test. Hum Mutat 2010, 31:866-874.

80. Fode $P$, Jespersgaard $C$, Hardwicks RJ, Bogle H, Theisen M, Dodoo D, Lenicek M, Vitek L, Vieira A, Freitas J, Andersen PS, Hollox EJ: Determination of Beta-Defensin Genomic Copy Number in Different Populations: A Comparison of Three Methods. PLoS ONE 2011, 6:16768.

81. Perry GH, Ben-Dor A, Tsalenko A, Sampas N, Rodriguez-Revenga L, Tran CW, Scheffer A, Steinfeld I, Tsang P, Yamada NA, Park HS, Kim J, Seo J, Yakhini Z, Laderman S, Bruhn L, Lee C: The fine-scale and complex architecture of human copy-number variation. Am J Hum Genet 2008, 82:685-695.

82. Choy KW, Setlur SR, Lee C, Lau TK: The impact of human copy number variation on a new era of genetic testing. BJOG 2010, 117:391-398.

doi:10.1186/1755-8166-6-8

Cite this article as: BoonPeng and Yusoff: The utility of copy number variation (CNV) in studies of hypertension-related left ventricular hypertrophy (LVH): rationale, potential and challenges. Molecular Cytogenetics 2013 6:8.

\section{Submit your next manuscript to BioMed Central and take full advantage of:}

- Convenient online submission

- Thorough peer review

- No space constraints or color figure charges

- Immediate publication on acceptance

- Inclusion in PubMed, CAS, Scopus and Google Scholar

- Research which is freely available for redistribution

Submit your manuscript at www.biomedcentral.com/submit
Biomed Central 